Ks. Wojciech Góralski

Wydział Prawa Kanonicznego UKSW

\title{
Metus reverentialis jako tytuł nieważności małżeństwa w świetle wyroku Roty Rzymskiej c. Erlebach z 13 grudnia 2007 r.
}

Tytuł nieważności małżeństwa określany zwrotem vis et metus (kan. $1103 \mathrm{KPK}$ ) nie przestał figurować na wokandach sądów kościelnych, co oznacza, że wolność w wyborze współmałżonka bywa nadal ograniczana, prowadząc niejednokrotnie do nieważnego zawierania związków małżeńskich.

Kan. 1103 KPK stanowi, iż „nieważne jest małżeństwo zawarte pod przymusem lub pod wpływem ciężkiej bojaźni pochodzącej z zewnątrz, choćby wywołanej nieumyślnie, od której, aby się uwolnić, zmuszony jest ktoś wybrać małżeństwo".

Szczególnym rodzajem bojaźni, o której mowa w przytoczonym kanonie, jest bojaźń szacunkowa (timor reverentialis), zachodząca $\mathrm{w}$ relacjach rodzice-dzieci oraz przełożeni-podwładni.

\section{I}

W rozpoznanej przez turnus rotalny c. Erlebach sprawie nullitatis matrimonii ${ }^{1}$ chodzi o małżeństwo zawarte 22 września 1992 roku przez Katarzynę (1. 19) i Jana (1. 21) po trzyletniej znajomości, która $\mathrm{w}$ ostatnich miesiącach doprowadziła strony do relacji intymnych. Związek ten, z którego przyszło na świat jedno dziecko, został zawarty mimo przeciwnego zamysłu kobiety. Życie wspólne małżonków układało się bardzo źle, tak że kilkukrotnie strony uciekały się do

1 R.P.D. Gregorio Erlebach. L. Nullitatis matrimonii, RRD 99 (2007), s. 336-347. 
czasowej separacji. Definitywne rozłączenie małżonków nastąpiło w lipcu 1998 roku, a więc po blisko sześciu latach od zawarcia związku; w następnym roku otrzymali rozwód cywilny. $\mathrm{W}$ międzyczasie oboje zawarli nowe małżeństwa cywilne.

W dniu 24 sierpnia 1998 roku Katarzyna zwróciła się do Trybunału Kościelnego pierwszej instancji o stwierdzenie nieważności swojego małżeństwa, nie wskazując żadnego tytułu nieważności; natomiast szeroko przedstawiła fakty dotyczące swojego przypadku.

Trybunał, kompetentny z racji miejsca zawarcia małżeństwa oraz stałego miejsca zamieszkania pozwanego skargę przyjął i wezwał Jana, który jednak nie stawił się ani w żaden sposób nie określił swojego stanowiska. Sprawę rozpoznawano z tytułu przymusu lub bojaźni po stronie powódki. Po przesłuchaniu tej ostatniej oraz trzech świadków z jej strony, a także pozwanego, który początkowo nie stawił się na zeznania i został uznany za nieobecnego (26 listopada 1999 roku), po czym usprawiedliwił swoje niestawiennictwo i złożył zeznanie, a następnie po podjęciu kolejnych etapów procesu, w dniu 31 grudnia 2001 roku sąd wydał wyrok negatywny.

Po złożeniu przez kobietę apelacji do Trybunału Metropolitalnego i ponownym przesłuchaniu sądowym matki Katarzyny, 14 października 2003 roku zapadł wyrok pozytywny, uchylając orzeczenie pierwszej instancji, stosownie do kan. $1682 \$ 1 \mathrm{KPK}$. Sprawa znalazła się z kolei w Trybunale Roty Rzymskiej (w trzeciej instancji, gdzie po ustanowieniu turnusu i przetłumaczeniu akt na język włoski - Dziekan wyznaczył powódce patronkę ex officio). Po wezwaniu pozwanego i wymianie pism obrończych, turnus rotalny c. Erlebach (pozostałymi sędziami byli A. Ciani i J. Ferreira Pena), w dniu 13 grudnia 2007 roku, wydał wyrok pro nullitate z tytułu przymusu i bojaźni po stronie powódki².

2 Tamże, s. 336-337. 
Punktem wyjścia dla ponensa w części poświęconej motywom prawnym orzeczenia jest wielce ceniona przez Kościół zasada wolności wyboru stanu życia, określona w kan. 219 KPK. Gdy wolność ta jest ograniczona od zewnątrz, kontrahent - mimo generalnej zasady wpisanej do kan. $125 \$ 2$ KPK o ważności aktu powziętego pod wpływem ciężkiej bojaźni - może odzyskać swój wolny stan w zakresie przytoczonej normy kan. $1103 \mathrm{KPK}$. W praktyce sądowej, wymieniony tytuł nieważności określany jest zwrotami vis vel metus i vis et metus (formuła ta ma swój sens wyjaśniający) albo po prostu metus, ze wskazaniem - w formule wątpliwości - strony, w stosunku do której miał być wywołany.

Przymus (vis), wyjaśnia redaktor orzeczenia, wskazuje tu przymus moralny, przy czym sam przymus (nie licząc przymusu fizycznego, o którym w kan. $125 \$ 1 \mathrm{KPK})$, z którego nie rodzi się bojaźń (metus), nie jest przyczyną nieważności zgody małżeńskiej; nie spowoduje tej nieważność także sama bojaźń, która nie pochodzi od przyczyny zewnętrznej, tj. wolnej, ludzkiej. W przypadku ograniczenia wolności od wewnątrz, w szczególności pochodzącej z pewnych anomalii natury psychicznej, mamy do czynienia $z$ brakiem rozeznania oceniającego (brak wolności wewnętrznej). W tak określonym zakresie tytułu nieważności vis vel metus należy więc mieć na względzie dwa wymogi postawione w kan. 1103 KPK: ciężkość i niezmienność (gravitas et indeclinabilitas) $)^{3}$.

Co się tyczy ciężkości bojaźni, głosi wyrok, to trzeba ją mierzyć nie tylko obiektywnie, tj. według zagrażającego zła, lecz również subiektywnie, tj. stosownie do jego wpływu na wolę ulegającego bojaźni. W konsekwencji sędzia powinien dokładnie rozważyć okoliczności rzeczy i osób, a przede wszystkim naturę gróźb oraz usposobienie właściwości sprawcy bojaźni i jej ofiary, a także wzajemną relację obu tych podmiotów ${ }^{4}$. Gdy chodzi z kolei o niezmienność bojaźni,

3 Tamże, s. 338.

4 Odwołano się tutaj do Dec. c. Ferreira Pena z 8 VI 2001, RRD 93 (2001), s. 377. 
to oznacza ona niemożliwość moralną uniknięcia zła, które zagraża, chyba że w drodze wyboru małżeństwa ${ }^{5}$.

Specjalnej uwagi, stwierdza Erlebach, wymaga tzw. bojaźń szacunkowa, która pochodzi z lęku przed niezadowoleniem i oburzeniem (niełaską) rodziców i przełożonych, czyli jest wzbudzana przez tych, w stosunku do których ktoś jest związany obowiązkiem szacunku i przywiązania. Tego rodzaju bojaźń polega na obawie zła płynącego z nieposłuszeństwa, gdy ktoś czyni coś z powodu lęku przed obrażeniem tych, którym powinien okazywać szacunek i posłuszeństwo ${ }^{6}$.

Chociaż karcenie stosowane ze strony rodziców lub przełożonych, zauważa ponens, nie wydaje się wewnętrznie (samo w sobie) ciężkie, to jednak także metus reverentialis może stać się ciężki, jeśli na podstawie okoliczności przewiduje się poważne i długotrwałe oburzenie rodziców albo wygaśnięcie ich relacji uczuciowej. To zaś przejawia się w naganach, uciążliwych i przykrych naleganiach, ostrych słowach, płaczu, natarczywych zachętach i powtarzających się narzekaniach na zagrażającą rodzinie szkodę. Bezwzględny rozkaz, przez który często rodzice „twardo” i w sposób surowy narzucają dzieciom małżeństwo, zawiera w sobie wirtualne groźby, które są w stanie wywołać bojaźń szacunkową. Dzieci bowiem, świadome nieugiętego i surowego usposobienia rodziców dobrze wiedzą z codziennego doświadczenia, że rodzice nieposłuszeństwo uważają za obelgę, i dlatego rodzi się w nich przerażenie umysłu (trepidatio mentis), a więc lęk, którego nie mogą

${ }^{5}$ Odwołano się w tym miejscu do Dec. c. Caberletti z 12 VI 2003, RRD 95 (2003), s. 363 .

6 „Peculiarem attentionem meretur s.d. metus reverentialis «qui ex timore displicentiae et indignationis parentum superiorumque exoritur, seu ab iis incutitur quo reverentiae et pietatis officio quis prosequi tenetur. Metus eiusmodi in formidine mali ex inobedientia impendentis consistit, qua quis aliquid facit propter timorem offendendi eos, quibus reverentiam et oboedientiam praestare debet (cf. coram Sabattani, sent. diei 11 novembris 1960, RRDec., vol. LII, p. 477, n. 3)» (coram Stankiewicz, sent. diei 12 iulii 1996, ibid., vol. LXXXVIII, p. 508, n. 4)”. R.P.D. Gregorio Erlebach. L. Nullitatis matrimonii, jw., s. 338. 
przezwyciężyć, ponieważ słusznie uważają, iż popadają w poważną niełaskę rodziców ${ }^{7}$.

W aplikowaniu sądowym kan. 1103, kontynuuje ponens, należy uwzględniać nie tylko rację kanonu, tj. ochronę wolności przeżywającego bojaźń, i oceniać wymogi wskazane w tymże kanonie, lecz - aby mogły być ujęte granice normy tam określonej - trzeba poznać również rację nieważności. Zważywszy, że powołany kanon może być aplikowany również do małżeństw akatolików ${ }^{8}$ i należy go traktować jako deklarację normy funkcjonującej mocą prawa naturalnego lub z samej natury zgody małżeńskiej, rację nieważności zgody małżeńskiej, wymuszonej ab extrinseco, należy uznać jedynie w granicach niewystarczającej woli konsensualnej. Mówiąc pozytywnie, $\mathrm{z}$ natury rzeczy wymaga się bowiem nie tylko rozeznania oceniającego proporcjonalnego do małżeństwa, lecz również woli proporcjonalnej do małżeństwa. Można zatem potwierdzić, iż konieczna jest wolność proporcjonalna do małżeństwa, tj. w takiej mierze, by kontrahent mógł dokonać autodeterminacji w stosunku do małżeństwa zawieranego hic et nunc z określoną osobą.

W praktyce sądowej, czytamy następnie w orzeczeniu, do rozstrzygnięcia, czy istnieje relacja przyczynowości między przymusem i wyborem małżeństwa ze strony przeżywającego bojaźń czy też nie, roztropny sędzia powinien zbadać, czy przeżywający bojaźń zawarł małżeństwo z powodu bojaźni (ob metum), czy tylko przeżywając bojaźń (cum metu). W tej ostatniej opcji bojaźń, owszem, „skaża” zgodę, lecz nie czyni jej nieważną.

Gdy chodzi o dowodzenie bezpośrednie przymusu i bojaźni, to redaktor wyroku zaznacza, że dokonuje się ono poprzez zwyczajne środki dowodowe, a więc zeznania sądowe stron, przede wszystkim domniemanej ofiary przymusu i ich świadków. Należy przy tym mieć na uwadze przede wszystkim to, że większe znaczenie mają zeznania

\footnotetext{
7 Odwołano się tutaj do Dec. c. Defilippi z 13 VII 2000, Vicentina, A. 77/00, n. 15 (nieopubl.).

8 Zob. Odpowiedź Papieskiej Komisji do Autentycznej Interpretacji KPK z 15 IV 1986, AAS 79 (1987), s. 1131.
} 
tych - jeśli są wiarygodni - którzy poświadczają przymus, niż tych, którzy go wykluczają; mniejsze bowiem znaczenie mają deklaracje co do faktu negatywnego, tj. takiego, który nie miał miejsca, niż co do faktu pozytywnego, tj. takiego, który został wykonany. Z kolei dowodzenie pośrednie obejmuje badanie awersji: czy miała miejsce w stosunku do drugiej strony, a przede wszystkim w stosunku do małżeństwa hic et nunc z nią zawieranego, czy też nie. Wszytko to należy zbadać w świetle okoliczności, które miały miejsce czy to przed zawarciem małżeństwa, czy też po jego zawarciu?.

\section{III}

W części wyroku poświęconej motywom prawnym stwierdza się na wstępie, że nie ma wątpliwości co do braku jakichkolwiek oznak przymusu w okresie relacji przedmałżeńskich stron, poczynając od zapoznania się 16. letniej uczennicy liceum ze starszym od niej o dwa lata Janem. Ten ostatni podobał się jej, choć nie zapewniała go o swojej miłości; natomiast często pytała go, czy ją kocha. Powódka w drugiej instancji wspomniała, że wzajemne odnoszenie się stron raz było sympatyczne, innym razem niesympatyczne; pozwany był dla niej atrakcyjny pod względem fizycznym.

Za coś stosownego uznał ponens nakreślenie osobowości Katarzyny. Znamienne było określenie przez nią samej siebie w drugiej instancji, kiedy to wyznała m.in., że musiała zabiegać o względy rodziców, czując się dzieckiem niechcianym, „niezaplanowanym”, w przeciwieństwie do o wiele bardziej faworyzowanej przez rodziców siostry. Innym razem powiedziała, że gdy poznała Jana, poczuła się dowartościowana i doceniona.

Stopniowo jednak, czytamy w orzeczeniu, rodziła się u powódki - w stosunku do pozwanego - pewna ambiwalencja. Poczynając od wyjazdu jej ojca do Iraku, musiał jej zawsze towarzyszyć Jan; nikt inny poza nim nie mógł jej wówczas odwiedzać; w tym okresie strony zainicjowały relacje seksualne, $\mathrm{z}$ inicjatywy mężczyzny. Znamienne jest

9 R.P.D. Gregorio Erlebach. L. Nullitatis matrimonii, jw., s. 337-339. 
tutaj stwierdzenie Katarzyny, iż wizyty Jana w jej rodzinnym domu mile widziała jej matka. W sytuacji nieporozumień między Katarzyną i Janem zawsze stawała po stronie tego ostatniego, wyraźnie okazując mu swoją życzliwość. Niejednokrotnie, gdy wizyta taka przedłużała się, a Katarzyna próbowała delikatnie oddalić Jana (chciała się uczyć), jej matka interweniowała, zatrzymując go jeszcze przez jakiś czas i mówiąc: „Zostań jeszcze 10 lub 15 minut, wkrótce będziecie razem na zawsze"10. Nic też dziwnego, że w tej sytuacji pozwany czuł się pewnie, niekiedy przychodził do domu powódki będąc pod wpływem alkoholu i domagał się od niej współżycia, co powodowało u niej agresję. Sama też spostrzegła, że jej relacje z Janem stały się ,ubogie”; że nie mają o czym rozmawiać, a ich spotkania stawały się „milczące”. Dodała, że w takich sytuacjach pozwany usiłował ją pocałować lub chciał współżyć z nią.

Jak stwierdza ponens, w stanie takiej ambiwalencji zaczął się rodzić u Katarzyny sprzeciw w stosunku do pozwanego. Dziwne jest to, że kwestia zaistniała nie między stronami, a raczej między powódką i jej matką. Katarzyna zeznała, iż usiłowała kiedyś matce wyjaśnić, że ona i Jan nie są „stworzeni jedno dla drugiego”, lecz matka obróciwszy się ku niej odpowiedziała bardzo wulgarnie: „Nie będą tu przychodzić jak psy do suki”. Według powódki miało to znaczyć, że poza pozwanym nikt nie będzie mógł do niej przychodzić. Dlatego też, jak dodała, dokądkolwiek się udawała, na jakąkolwiek imprezę, musiała iść z Janem.

Według powódki, jak podkreśla się w orzeczeniu, jej matka była przeciwna zerwaniu przez córkę relacji z Janem i różnymi sposobami wywierała na nią presję. Katarzyna w swoim zeznaniu wyznała, że gdy uczęszczała do szkoły, niejednokrotnie matka ją spoliczkowała ponieważ sprzeciwiała się jej co do relacji z pozwanym. Wiele razy sugerowała jej, by dbała bardziej o wygląd i lepiej się ubierała, by

\footnotetext{
10 „Spesso gli chiedevo di andare via perché dovevo studiare, allora lui alzava la voce e nella mia camera entrava mia madre fermandolo e difendendolo. Mia madre diceva: rimani ancora 10 o 15 minuti, tra poco sarete insieme per sempre”. - Tamże, s. 340 .
} 
podobać się Janowi. Dla osiągnięcia swojego celu matka Katarzyny podejmowała niewiarygodne machinacje, a na potwierdzenie swoich słów posłała ją do wróżki, do której musiała pójść. Sądziła, że wróżka powie jej różne rzeczy, tymczasem gdy powódka jej powiedziała, że ma chłopca, natychmiast karty wróżki wskazały na miłość. Mówiła jej, że się bardzo kochają (strony) i z pewnością się pobiorą. Powódka wiedziała, że jej matka była wcześniej u wróżki; posługiwała się swoimi służbami.

W wyroku zwrócono następnie uwagę na jeszcze inną kwestię: dotyczącą możliwości kontynuowania przez powódkę studiów uniwersyteckich po egzaminie dojrzałości. Otóż rodzice kategorycznie oświadczyli jej, że musi na ten temat porozmawiać jedynie z pozwanym, o którym wiedzieli, że nie wyrazi na to zgody.

Ponens zwraca z kolei uwagę na to, że w wyroku (jak wspomniano na wstępie, negatywnym) pierwszej instancji, sędziowie przypisali duże znaczenie oświadczeniu pozwanego o propozycji zawarcia małżeństwa pochodzącej od powódki. Według Jana miało to mieć miejsce na około sześciu miesięcy przed ślubem; powódka miała to uczynić, gdy jej siostra planowała własne małżeństwo. Strony miały wtedy, jak zeznał Jan, coraz częściej mówić o małżeństwie.

Jak się okazało, czytamy w orzeczeniu, powódka nic na ten temat nie powiedziała w pierwszej instancji. Sądziła z pewnością, tłumaczy ponens, że tego rodzaju propozycja, w jakikolwiek sposób uczyniona, przemawiałaby przeciw tezie o zgodzie małżeńskiej wymuszonej. Dopiero w zeznaniu złożonym w drugiej instancji podała własną wersję na ten temat. Stwierdziła mianowicie, że wszystko zostało wymyślone bardzo spontanicznie w dniu zaręczyn jej siostry. Powiedziano, że także ona i Jan pobiorą się. Dodała, że między nią a siostrą trwała rywalizacja. Zostało więc powiedziane, powtórzyła, bez zastanowienia, że także ona wyjdzie za mąż, tak jak jej siostra i będzie miała swoich gości (jakkolwiek powódka użyła tutaj formy bezosobowej, to $\mathrm{z}$ kontekstu wynika, że to ona tak mówiła).

Idea zawarcia małżeństwa, konkluduje w tym fragmencie Erlebach, została ujawniona na forum rodzinnym w okresie ambiwalentnej pozycji powódki. 
W kolejnym fragmencie orzeczenia ponens stwierdza, że wszyscy są zgodni co do prawdziwego i osobistego sprzeciwu Katarzyny wobec małżeństwa $\mathrm{z}$ Janem, które miało zostać zawarte, który to sprzeciw miał swój początek trzy lub cztery tygodnie przed ślubem.

Gdy chodzi o samą powódkę, w wyroku przytoczono fragment jej zeznania w pierwszej instancji, kiedy to powiedziała, że sytuacja znacznie się pogorszyła po wygłoszeniu zapowiedzi przedślubnych. Między stronami miała miejsce ostra wymiana słów, a pozwany jasno widział, że Katarzyna go nie akceptowała. Po wygłoszeniu zapowiedzi powódka prosiła rodziców o zmianę ich opinii i uwolnienie jej od Jana. Rodzice jednak zakomunikowali córce, że musi za niego wyjść, nazywając ją głupią, obrażając ją i używając wulgarnych słów.

Pozwany, ze swej strony, jak relacjonuje ponens, zeznał, że na trzy tygodnie przed zawarciem małżeństwa powódka prosiła go o rozmowę, podczas której powiedziała mu, że go nie kocha i nie chce zawierać z nim małżeństwa, czym poczuł się bardzo zraniony. Prosił ją wówczas, by się zreflektowała i zmieniła decyzję, ona jednak nie zgodziła się na to. Po pewnym czasie, po tygodniu, udał się do rodziny powódki, by rozmawiać o motywie, dla którego nie wyrażała zgody na małżeństwo. Nadmienił także, iż w tym momencie można było zauważyć pragnienie matki powódki, by córka zawarła z nim małżeństwo. Po dyskusji trwającej kilka godzin powódka, czego był świadkiem, wyraziła zgodę na małżeństwo.

W zakończeniu tego spotkania rodzinnego, konstatuje redaktor wyroku, Katarzyna niewątpliwie zgodziła się zewnętrznie na zawarcie tego małżeństwa. Czy jednak, pyta retorycznie, decyzja ta była aktem autodeterminacji, czy raczej posłuszeństwa wobec rodziców, przede wszystkim wobec matki? Jaka więc była racja wyrażenia tej zgody ze strony powódki?, pyta.

$\mathrm{W}$ odpowiedzi ponens stwierdza najpierw, że pozwany deklaruje, iż po owym spotkaniu u rodziny powódki ta ostatnia nie zgłaszała więcej trudności, i w tym okresie, aż do samego końca, tj. do 12 września (chodziło o 22 września) było tak, jak powinno być. Nie było ze strony powódki żadnego sprzeciwu. 
Obszerniejszy fragment orzeczenia został poświęcony zeznaniom powódki. Katarzyna - stwierdza się na wstępie - zeznała coś przeciwnego wyjaśniając, że dwa lub trzy tygodnie przed zawarciem małżeństwa, gdy powiedziała „nie”, nie mogła mieć kontaktów ani ze swoją siostrą ani nawet ze znajomymi, by ktokolwiek wsparłby ją w jej decyzji. Jej matka śledziła ją w tym, co robiła; czuła się osaczona. Już w pierwszej instancji jasno przedstawiła swoje stanowisko mówiąc, że nie zawarła małżeństwa dobrowolnie, została bowiem zmuszona do tego przez swoich rodziców, a w szczególny sposób przez matkę ${ }^{11}$. Wskazała także na motyw swojego sprzeciwu: nie chciała poślubić pozwanego, ponieważ nie podobał się jej jako towarzysz życia; nie podobała się jej agresywność Jana, nie tolerowała jego osoby.

Również przed sędzią w pierwszej instancji, kontynuuje ponens turnusu rotalnego, powódka zreasumowała sposoby, którymi została pozbawiona wolności w relacji do zawartego małżeństwa: nikt nie mógł jej odwiedzać poza pozwanym; nie mogła wychodzić z domu z jakąkolwiek inną osobą, lecz zawsze z pozwanym, którego nie akceptowała; dwa ostatnie lata nauki w szkole upłynęły jej jako ustawiczne zmuszanie ją do małżeństwa z pozwanym poprzez ukazywanie, wyjaśnianie i przekonywanie jej co do dobrych stron Jana; matka stosowała wobec niej przymus fizyczny (policzkowanie); podjęcie przez nią studiów rodzice uzależnili od decyzji pozwanego; nie mogła absolutnie decydować o sobie samej, czyniąc wszystko pod dyktando matki, która ją molestowała, tak iż przeżywała lęk; była całkowicie zależna od rodziców, nie miała pieniędzy i nawet własnego domu; rodzice grozili jej wyrzuceniem $\mathrm{z}$ domu.

W tym „wykazie” form przymusu, zauważa ponens, powódka dała jednostronny opis powstały, być może, w świetle doświadczenia, które dojrzewało w niej bezpośrednio przed ślubem. Należy bowiem rozróżnić czas ewolucji w jej relacji z pozwanym. Sama bowiem wyznała, że pierwsze dwa lata liceum były okresem „oczarowania” pozwanym, natomiast w ciągu kolejnych dwóch lat dawała sygnały, iż nie akceptuje

\footnotetext{
11 „Non mi sponsavo liberamente. Mi hanno costretto a ciò i miei genitori, e in modo particolare mia madre”. - Tamże, s. 343.
} 
go i że nie może on być partnerem jej życia. Jego osobowość oraz sposób bycia nie podobały się powódce. Po wygłoszeniu zapowiedzi przedślubnych sytuacja zaczęła zmierzać ku „ruinie”.

Ponens dostrzega ponadto, iż ze strony powódki brak jest jakiegokolwiek elementu, by można było utrzymywać, że zmieniła ona szczerze swój zamysł i dobrowolnie przystąpiła do ślubu. Co więcej, wszystko prowadzi do przyjęcia, że jej wola została złamana w skutek interwencji rodziców, zwłaszcza matki. Odzwierciedlają to słowa Katarzyny, jakie padły z jej ust w drugim zeznaniu, gdy oświadczyła, że z powodu tego małżeństwa miało miejsce tyle kłótni, iż była tą sytuacją wyczerpana.

Znamienny jest także przytoczony w orzeczeniu rotalnym opis samej celebracji małżeństwa nakreślony przez powódkę. Stwierdziła mianowicie, iż w momencie przysięgi czuła się dziwnie, wstydziła się wychodzić za mąż. Odczuwała gniew, że stała za nią matka. Podczas ślubu myślała, by powiedzieć: „nie”. Gdy wypowiadała słowa przysięgi pełnym głosem, żywiła wewnętrzne przekonanie, że słowa te były dla innych osób, a nie dla niej. Słowa, które wypowiedziała, nie miały dla niej żadnego znaczenia. Szerzej to wyjaśniła, nadmieniono w wyroku, $\mathrm{w}$ swoim drugim zeznaniu, i to $\mathrm{w}$ tym samym znaczeniu ${ }^{12}$.

Przechodząc do oceny zeznań świadków, ponens przytacza najpierw relację rodziców powódki.

Jej matka, podkreśla, przyjęła co do istoty, choć ze smutkiem, zeznania swojej córki. Wyznała bowiem, iż wywierała pewną presję na Katarzynę, ta zaś wyrażała swoje zastrzeżenia co do pozwanego, iż nie będzie dla niej partnerem w małżeństwie, a na krótko przed ślubem odnosiła się do świadka z gniewem i nie chciała zawierać małżeństwa. Składając zeznania, świadek uznała swoją odpowiedzialność, wyrażają żal z powodu swojej postawy i z powodu zawarcia przez córkę małżeństwa $\mathrm{z}$ pozwanym.

Ojciec powódki potwierdził wolę córki odwołania zgody na małżeństwo, on jednak i jego żona nie chcieli „odwoływać” tego małżeństwa, gdyż wszystko było już przygotowane. Nacisk na zawarcie

12 Tamże, s. 333-334. 
małżeństwa wywierali - zdaniem świadka - także rodzice pozwanego. Świadek potwierdził poza tym awersję córki do małżeństwa z Janem; wyznał też otwarcie: „Moja córka mówiła, że nie chce go poślubić"13.

W tym samym duchu, czytamy w wyroku, zeznawała siostra powódki A., podkreślając, że Katarzyna nie zawierała małżeństwa dobrowolnie, lecz pod presją rodziców, ponieważ go nie kochała. Powiedziała również, że półtora miesiąca przed zawarciem tego związku miały miejsce naciski obu stron (rodziców), ponieważ wszystko było przygotowane do małżeństwa i rodzinom groził wstyd. Świadek wspomniał ponadto i o tym, że jej siostra broniła się przed małżeństwem, lecz czuła lęk przed konsekwencjami, a rodzice pozwanego często telefonowali do ich domu i przekonywali do małżeństwa; Katarzyna narzekała do świadka oraz do znajomych na życie pod presją. Za szczególnie cenną informację świadka ponens uznał wzmiankę na temat relacji zachodzącej między Katarzyną i jej rodzicami w okresie bezpośrednio poprzedzającym zawarcie małżeństwa: powódka była wówczas niezdecydowana, obawiała się sprzeciwu wobec rodziców, także oni byli w tym okresie bardzo podnieceni, nic nie mówili do innych, obawiali się o opinię u tych osób. Świadek potwierdziła także zeznanie powódki dotyczące dnia ślubu: Katarzyna była zamyślona, bez uśmiechu; wyznała świadkowi, że w czasie wyrażania zgody małżeńskiej myślała przeciwnie (mówiła „tak”, myślała „nie”).

Zeznania świadków, konkluduje ponens, w pełni potwierdzają tezę Katarzyny. I choć są to świadkowie z rodziny powódki, a przy tym nieliczni, dodaje, to jednak cieszą się bardzo dobrymi świadectwami wiarygodności, w przeciwieństwie do pozwanego.

Jak zaznaczono w orzeczeniu, tezie o wymuszonej zgodzie małżeńskiej sprzyja także dowód z życia wspólnego stron, które było najgorszej jakości. Matka Katarzyny zeznała, iż po ślubie praktycznie małżeństwo „szło” zupełnie źle. A sama powódka powiedziała m.in., że strony często się sprzeczały z banalnych powodów. Rzadko miewali

13 „Mia figlia diceva di non volerlo sposare”. - Tamże, s. 344. 
relacje intymne, na które wyrażała zgodę wówczas, gdy potrzebowała pieniędzy. Nie chcieli być razem, często pozostawali w separacji.

Pozwany nie przyjął swojej części odpowiedzialności, lecz dokładnie określił, iż separacja miała miejsce 8-9 razy, zawsze z inicjatywy powódki ${ }^{14}$.

Z kolei ponens wykazuje błędną interpretację faktów dokonaną w pierwszej instancji. Tak więc w odniesieniu do okresu mającego miejsce bezpośrednio przed zawarciem małżeństwa w wyroku stwierdzono, że kilka tygodni przed zaplanowanym ślubem powódka zmieniła swoje zapatrywanie w tej kwestii. Decyzję tę tłumaczą jej ewidentną tendencją do działań impulsywnych bez uwzględnienia konsekwencji. Według sędziów wymienionej instancji rodzice powódki, w szczególności matka, mając na względzie niestałą emocjonalnie osobowość córki, podjęli z nią chętnie dyskusję. W wyniku tych rozmów ta ostatnia zaakceptowała stanowisko swoich rodziców i wyraziła na nowo zgodę na zawarcie małżeństwa; intencja stworzenia wspólnoty małżeńskiej z pozwanym towarzyszyła powódce podczas przygotowań do ślubu oraz w momencie wyrażania zgody małżeńskiej.

Jedyną podstawę do utrzymania twierdzenia o tendencji powódki do działań impulsywnych, stwierdza ponens rotalny, stwarza zeznanie jej matki, według której Katarzyna ma charakter, który często się zmienia; jeśli mówi coś złego, reflektuje się i przeprasza, jakby niczego nie było. Lecz to, wyjaśnia tenże ponens, w rzeczywistości wskazuje również na racjonalny sposób postępowania, choć poprzez decyzje powzięte ex post. Poza tym potwierdza to również skłonność Katarzyny do nawiązania pokojowych relacji z jej rodzicami. To wyjaśnia lepiej, dlaczego powódka poddała się woli matki. W tym też duchu zeznała ona sama $\mathrm{w}$ drugiej instancji podając jeden $\mathrm{z}$ motywów, dla których przystąpiła do małżeństwa: „Powiedziałam, że nie chciałam tego małżeństwa. Powstała nowa sprzeczka. Moja mama była bardzo wrażliwa: kupiła ubranie. Przykro mi było z uwagi na nią, że mogę zrobić jej źle. Nie chciałam być przyczyną jej cierpień,

14 Tamże, s. 344-345. 
jej płaczu. Ostatecznie, w dniu małżeństwa, powiedziałam do mojej mamy, że to jest jej małżeństwo, nie moje"15.

Cokolwiek jest, stwierdza się dalej w wyroku, to biorąc pod uwagę także drugie zeznanie sądowe powódki, złożone w drugiej instancji, i to, co bezpiecznie można przyjąć, to nie pozostaje żadna rozumna wątpliwość co do podstawowej tezy tejże kobiety: przystąpiła do małżeństwa nie tylko z bojaźnią (cum metu), lecz z powodu bojaźni (ob metum). Chodzi w tym przypadku o bojaźń szacunkową: z jednej strony młoda kobieta była przed zawarciem małżeństwa bardzo wrażliwa (potwierdza to pozwany mówiąc, że była bardzo wrażliwa i również bardzo bezbronna), z drugiej zaś strony oznaki sprzeciwu powódki, następnie także jej ujawniona wola przeciw zawarciu małżeństwa wywołały bezpośrednie reakcje jej rodziców, przede wszystkim matki, która różnymi sposobami, godziwymi i niegodziwymi, przez długi okres czasu stosowała przemoc w stosunku do Katarzyny. Biorąc pod uwagę okoliczności życia i usposobienia powódki, wszystko to należy uznać za całkowicie ciężki przymus, z powodu którego Katarzyna musiała zawrzeć małżeństwo, nie mając innego realnego rozwiązania ${ }^{16}$.

Ustosunkowując się wreszcie do uwag obrońcy węzła małżeńskiego, ponens uchyla najpierw jego obiekcję, iż nie udowodniono poważnej awersji powódki do pozwanego, a przede wszystkim do małżeństwa z nim. Na poparcie tego twierdzenia obrońca wskazał jedynie na elementy, które odnoszą się do początku relacji przedślubnej stron oraz do okresu kolejnego, który znamionowało dwuznaczne stanowisko kobiety, tymczasem awersję Katarzyna wyraźnie okazała dopiero w ostatnim miesiącu przed ślubem, o czym już wspomniano.

\footnotetext{
15 „Io ho detto che non volevo questo matrimonio. Ci è stato un altro litigo. Mia mamma era molto tenera: comprava il vestito. Mi dispiaceva per lei, che io potessi farle del male. Non volevo essere la causa delle sue sofferenze, del suo pianto. Finalmente, nel giorno del matrimonio, ho detto a mia mamma che questo è il suo matrimonio, non il mio". - Tamże, s. 345.

16 Tamże, s. 345-346.
} 
Druga trudność obrońcy węzła dotyczyła tego, iż to sama powódka zaproponowała małżeństwo, który to zarzut został implicite uchylony we wcześniejszym fragmencie wyroku.

Ponadto zdaniem obrońcy, świadkowie w sprawie nie potwierdzili jasno w swoich zeznaniach istnienia całkowitej awersji u powódki, która to awersja mogłaby „zakazić” konsens w stosunku do pozwanego. Ponens odpowiada, że wszyscy są zgodni w tym, że tylko na kilka dni przed ślubem Katarzyna ujawniła swój sprzeciw wobec małżeństwa, co też podkreśliła w swoim restrictus iuris et facti jej patronka ${ }^{17}$.

Od siebie autor wyroku wyjaśnia fakt przyjścia na świat dziecka w małżeństwie stron, który to fakt primo ictu wydaje się być przeciwny tytułowi nieważności małżeństwa, o który chodzi w sprawie. Wyraża jednak przekonanie, że miarodajne jest tutaj wyjaśnienie patronki powódki, która podkreśliła, że urodzenie się jednego dziecka nie jest znakiem uczucia między stronami. Powódka w swoim zeznaniu mówiła zresztą o bardzo złym życiu seksualnym między stronami po zawarciu małżeństwa. Zazwyczaj używała środków antykoncepcyjnych, jednak poczęcie dziecka miało miejsce po imprezie, kiedy oboje byli pod wpływem alkoholu ${ }^{18}$.

Ponens stwierdza w podsumowaniu, że nie ma żadnej trudności w uznaniu przytoczonego tytułu nieważności małżeństwa, jak to bardzo dobrze wykazali sędziowie Trybunału Apelacyjnego.

Dyspozycja „Affirmative, seu constare de nullitate matrimonii, in casu, ob vim et metum mulieri actrici incussum" kończy wyrok.

\section{IV}

Sprawa rozstrzygnięta ostatecznie w trzeciej instancji (rotalnej), która potwierdziła orzeczenie pro nullitate, jakie zapadło w drugiej instancji, stanowi interesujący przypadek dotyczący bojaźni szacunkowej (timor reverantialis).

17 Tamże, s. 346.

18 Tamże, s. 346-347. 
Według słynnej definicji kard. J. D’Annibale (zm. 1892) bojaźń szacunkowa to „domniemany sąd przyszłego zła, którego boimy się ze strony tych, pod których władzą się znajdujemy"19; zarówno w doktrynie, jak i w orzecznictwie uważana jest za rodzaj przymusu moralnego, w którym presja polega nie tyle na groźbach, ile raczej na okazywaniu jej ofierze oburzenia i gniewu, gdy sprzeciwia się woli rodziców lub przełożonych skłaniających ją (prośbami, perswazją, naleganiem) do zawarcia małżeństwa ${ }^{20}$.

W części In iure wyroku, Erlebach bardzo jasno przytacza zasady dotyczące wpływu bojaźni szacunkowej na ważność zgody małżeńskiej (a tym samym na ważność małżeństwa), zwraca przy tym uwagę na okoliczności, w których timor reverentialis, z natury swojej lekki, może stać się ciężki (tzw. kwalifikowany) i jednocześnie nieodwracalny, a więc taki, od którego doznający bojaźni może się uwolnić wyłącznie przez zawarcie małżeństwa ${ }^{21}$; $z$ natury rzeczy jest to bojaźń pochodząca ab extrinseco. Mówiąc inaczej, ponens chce podkreślić, że bojaźń szacunkowa, by spowodować nieważność małżeństwa, musi wyczerpywać wszystkie znamiona bojaźni określone w kan. 1103 KPK.

W piśmiennictwie nieczęsto dotyka się kwestii rozróżnienia ratio legis wymienionej normy prawnej i ratio nullitatis consensus matrimonialis coacti. Poszukując tej ostatniej, audytor rotalny uwzględnia znaczącą odpowiedź ówczesnej Papieskiej Komisji do Autentycznej Interpretacji KPK z 15 kwietnia 1986 roku i wskazuje tutaj na niewystarczającą wolę konsensualną. W związku z tym akcentuje konieczność (wynikającą z natury rzeczy) dysponowania przez nupturienta nie tylko proporcjonalnym - w stosunku do małżeństwa - rozeznaniem oceniającym, lecz również „wolą proporcjonalną do

\footnotetext{
19 „Futuri mali existimatio, quod ab his metuimus in quorum potestate sumus”. - J. D'Annibale, Summa theologiae moralis, t. 3, Romae 1897, s. 127.

20 Zob. G. Boni, Il timore reverenziale, w: P. A. Bonnet, C. Gullo (red.), Diritto matrimoniale canonico, t. 2: Il consenso, Città del Vaticano 2003, s. 517-518.

21 Zob. G. Caberletti, I requisiti del „metus” invalidante il consenso coniugale, w: P. A. Bonnet, C. Gullo (red.), Diritto matrimoniale canonico, t. 2: Il consenso, dz. cyt., s. 601-602.
} 
małżeństwa", a więc zdolnością do autodeterminacji w odniesieniu do małżeństwa zawieranego tu i teraz z określoną osobą.

Bardzo istotnym problemem, który poruszono w orzeczeniu, jest relacja przyczynowości, zachodząca między przymusem (rodzącym bojaźń) a wyborem małżeństwa przez doznającego bojaźni. Chodzi tu o znane - tak w doktrynie, jak i w orzecznictwie - rozróżnienie pomiędzy małżeństwem zawartym cum metu a małżeństwem zawartym ob metum, inaczej ex metu. W pierwszym przypadku mamy do czynienia z tzw. bojaźnią towarzyszącą (metus concomitans), która ma miejsce wówczas, gdy kontrahent wyraża zgodę małżeńską dla innych motywów, niezależnie od wywieranej na niego presji przez rodziców lub przełożonych; brak wówczas związku przyczynowego między działaniem sprawcy bojaźni a wolą zawarcia małżeństwa przez tego, kto doznaje bojaźni. Nieważność małżeństwa płynie tylko z takiej bojaźni, która jest jedyną przyczyną zawarcia tego związku, a więc ob metum.

Aplikując jasno wyeksplikowane zasady dotyczące rozumienia timor reverentialis do rozpoznawanego przypadku małżeństwa Katarzyny, sędziowie rotalni, dysponujący niezbyt obfitym materiałem dowodowym (zeznania stron oraz trojga świadków, wskazanych przez powódkę), dokonali jego wnikliwej i wszechstronnej analizy dochodząc do wniosku, iż powódka zawarła małżeństwo ob metum: pod wpływem bojaźni wywołanej przez jej rodziców, a w sposób szczególny przez matkę.

Duże znaczenie dla pozytywnego rozstrzygnięcia sprawy miało niewątpliwie uznanie (na podstawie świadectw) pełnej wiarygodności powódki (w przeciwieństwie do pozwanego). Ze zrozumiałych zresztą względów jej zeznania złożone przed trybunałami miały szczególne znaczenie. Nie oznacza to bynajmniej, że sędziowie bezkrytycznie Katarzynie zawierzyli. Jej zeznania zostały poddane ocenie w kontekście okoliczności sprawy pochodzących ze wszystkich okresów „biografii” tego związku.

Ponens „wydobył” z akt sprawy wszystkie momenty, które - inaczej interpretowane niż to uczynili sędziowie w pierwszej instancji - pozwoliły poznać obiektywną prawdę o małżeństwie stron. Zostały 
uwzględnione wszystkie etapy znajomości tychże stron: od ich poznania się aż do wyrażenia przez nie zgody małżeńskiej. Nic też dziwnego, że w wyroku rotalnym nie zabrakło „wytknięcia” sądowi pierwszej instancji arbitralnej oceny faktów.

Wnikliwie została poddana analizie osobowość - zarówno matki powódki, jak i tej ostatniej oraz wzajemne ich realcje. Katarzyna jawi się jako osoba solidna, szczera, pragnąca dobrych relacji z rodzicami, zabiegająca o ich względy, wrażliwa, pragnąca pogłębiać wiedzę, odpowiedzialna i na serio traktująca małżeństwo. Jej matkę zaś znamionowała również wrażliwość, a poza tym troska o los córki (niekiedy zbytnia), lecz także podejście do niej apodyktyczne.

Na uwagę zasługuje wspomniane wyżej, dokładne wniknięcie przez turnus rotalny w postawę i stanowisko Katarzyny w różnych okresach jej relacji z pozwanym, czego nie uwzględnili - w wystarczającej mierze - sędziowie drugiej instancji. Znacząca w wyroku c. Erlebach jest charakterystyka drugiego okresu znajomości stron, kiedy to powódka zaczęła okazywać swój sprzeciw wobec bliskiej relacji z pozwanym. Trafne jest przy tym zwrócenie uwagi nie tyle na wzajemną relację stron w tym okresie, ile na „zaostrzającą się” relację powódki i jej matki. Szczególnie baczną uwagą został objęty okres od wygłoszenia zapowiedzi przedślubnych aż do celebracji małżeństwa; głębiej wniknięto tutaj w motywy Katarzyny sprzeciwiającej się małżeństwu z Janem. Nie zabrakło też swoistego wyeksponowania (aż dziewięciu) sposobów, którymi zagrożona była wolność powódki w stosunku do zawarcia małżeństwa.

W uzasadnieniu decyzji audytorów rotalnych nie pominięto dowodu pośredniego - awersja powódki dotyczyła nie tylko Jana, ale i samego małżeństwa $\mathrm{z}$ nim.

Bardzo wymownie ukazał ponens sam moment zawierania przez strony małżeństwa, podobnie jak ukazał jakość życia wspólnego małżonków.

Znamienne jest także to, że ponens ustosunkował się do uwag obrońcy węzła małżeńskiego, przekonująco uchylając zgłoszone przez niego zastrzeżenia. 
Zarówno w części In iure, jak i w części In facto nietrudno dostrzec narrację dobrze uporządkowaną chronologicznie i właściwie ukierunkowaną merytorycznie, konsekwentne trzymanie się myśli przewodniej, wewnętrzną spójność przyjmowanych tez, trafność w wyciąganiu wniosków, umiar w przytaczaniu zeznań stron i świadków (w wielu wyrokach trybunałów niższych instancji tego brak), jasność w formułowaniu myśli.

Niewątpliwie, wyrok Roty Rzymskiej c. Erlebach stanowi znaczący przyczynek w procesie utrwalania linii orzeczniczych wymienionego Trybunału w odniesieniu do tytułu nieważności timor reverentialis.

\section{Metus reverentialis as a marriage invalidity title in the light of the verdict of the Roman Rota c. Erlebach as of 13.12.2007}

\section{Summary}

The author presents and comments on the judgment of the Roman Rota c. Erlebach in the matter of nullitatis matrimonii, which was passed on 13 December, 2007 in the third instance as per reverential fear (timor reverentialis). It is about the marriage concluded on 22 September, 1992 by Katarzyna and Jan. In this relationship which was concluded against the intentions of the woman one baby was born. Joint life of spouses was progressing very badly, therefore, the couple sought temporary separation several times. The definite separation of spouses took place in July, 1998 after almost six years from the conclusion of the marriage.

On August 24, 1998 Katarzyna turned to the ecclesiastical court of first instance for the court to decide about the invalidity of her marriage, not indicating any other invalidity title; while she broadly presented facts regarding her case. The case was heard de facto with consideration paid to the fear on the side of the plaintiff. Having heard the plaintiff and three witnesses on her side as well as the defendant and then after taking subsequent stages of the process on 31 December, 2001 the court gave a negative judgment.

After submitting by the woman of the appeal to the court of appeal and after another court hearing of Katarzyna's mother on 14 October, 2003 the judgment was positive, while the case found its way to the Roman Rota (as the third instance), where the rota Turnus c. Erlebach (the remaining judges were A. Ciani and J. Ferreira Pena) on 13 December, 2007 issued a pro nullitate judgment. 